\title{
DESCRIPTION OF DEPRESSION SYMPTOMS IN HEMODIALYSIS PATIENTS AT JEMURSARI HOSPITAL, SURABAYA
}

\author{
Yuyun Tri Wulansari ${ }^{1}$, Chatarina U. W. ${ }^{1}$ \\ ${ }^{1}$ Epidemiology Department, \\ Faculty of Public Health, Airlangga University, Surabaya, Indonesia \\ Correspondence Address: Yuyun Tri Wulansari \\ Email: yuyuntws@gmail.com
}

\begin{abstract}
Chronic kidney disease is decreasing glomerular filtration rate of less than $15 \mathrm{~mL} / \mathrm{minute}$ which causes someone to undergo a hemodialysis therapy that replaces kidney function. The course of chronic kidney disease is progressive and irreversible and may cause psychological problems in hemodialysis patients such as depression. This study aimed to describe to what extent patients under hemodialysis treatment at Jemursari Hospital, Surabaya experience depression symptoms in patients. This study was descriptive research with a cross-sectional approach. The simple random sampling technique was performed to select 72 patients who had scheduled hemodialysis treatment and been qualified for the inclusion criteria. Data were then analyed using a univariate analysis in variable frequency distribution. The results show that patients with depression symptoms were mostly men as many as 31 people (43.1\%), and the majority were aged 46-65 years as many as 24 people (49\%). The latest formal education in most respondents was high school (23.6\%). There were 38 respondents $(77.5 \%)$ who got married, and most respondents were unemployed $(77.5 \%)$ and had undergone hemodialysis for more than 12 months (77.5\%). This study concludes that the patients under hemodialysis treatment at the hospital experienced mild depression symptoms.
\end{abstract}

Keyword: hemodialysis, depression, Beck Depression Inventory.

\begin{abstract}
ABSTRAK
Penyakit ginjal kronik merupakan kondisi penurunan laju filtrasi glomerulus kurang dari $15 \mathrm{~mL} / \mathrm{menit}$ yang menyebabkan ginjal membutuhkan terapi hemodialisis sebagai pengganti fungsi ginjal. Perjalanan penyakit ginjal kronis bersifat progresif dan ireversibel yang berisiko menimbulkan masalah psikologis pada pasien hemodialisis seperti depresi. Penelitian ini bertujuan untuk mengetahui gambaran tingkat gejala depresi pada pasien hemodialisis di RSI Jemursari Surabaya. Desain yang digunakan dalam penelitian ini adalah penelitian deskriptif dengan pendekatan potong lintang. Penelitian ini menggunakan teknik sampling acak sederhana untuk memilih 72 pasien yang menjalani perawatan hemodialisis reguler (terjadwal) dan yang memenuhi kriteria inklusi. Teknik analisis data yang digunakan adalah analisis univariat dengan melihat distribusi frekuensi variabel. Hasil menunjukkan sebagian besar pasien yang mengalami gejala depresi adalah laki-laki sebanyak 31 orang (43,1\%), dan mayoritas berusia 4665 tahun sebanyak 24 orang (49\%). Jenjang pendidikan formal terakhir yang ditempuh adalah SMA (23,6\%). Mayoritas responden berstatus menikah (77,5\%), dan tidak bekerja (77,5\%) dan telah menjalani hemodialisis lebih dari 12 bulan (77,5\%). Kesimpulan dari penelitian ini adalah sebagian besar pasien di rumah sakit tersebut mengalami gejala depresi ringan.
\end{abstract}

Kata kunci: hemodialisis, gejala depresi, Beck Depression Inventory.

\section{INTRODUCTION}

Chronic Kidney Disease (CKD) is kidney damage that occurs for more than three months or a decrease in Glomerular Filtration Rate (GFR) of less than $60 \mathrm{~mL} / \mathrm{min}$
/ $1.73 \mathrm{~m} 2$ (Category GFR G3a - G5) (KDIGO, 2012).

Based on the 2013 Basic Health Research, the prevalence of chronic kidney disease in Indonesia was diagnosed by doctors at $2 \%$. The highest prevalence of 
chronic kidney disease occurred in Central Sulawesi at $0.5 \%$, while the prevalence in East Java was at $0.3 \%$ (Ministry of Basic Health Research, 2013). In 2015, the national health insurance burden of $\mathrm{Rp} 16.9$ trillion was allocated to fund treatment cost of catastrophic diseases such as heart disease, kidney failure, and stroke (Social Health Insurance Administration Agency (BPJS), 2016).

According to the Indonesian Renal Registry (IRR), the number of hemodialysis patients, both new and active patients, continues to increase every year. In 2016, there were 52,835 active patients and 25,446 new patients. In 2017, the number of active patients and new patients increased up to 77,892 and 30,831, respectively. In 2018, East Java was ranked the second province with the largest number of new patients after West Java province with 4828 new patients (Indonesian Renal Registry, 2018).

Hemodialysis therapy is needed for a person who experiences a decrease in glomerular filtration rate of less than 15 $\mathrm{mL} / \mathrm{min}$, or it can be said that someone has kidney failure (National Kidney Foundation, 2013). The Regulation of Indonesian Ministry of Health No. 812 of 2010 describes hemodialysis as a substitute therapy for kidney function which aims to excrete uremic toxins and regulate body fluid and electrolyte balance.

Hemodialysis patients are in an uncomfortable condition because their survival depends on hemodialysis therapy during their lifetime. The progressive and irreversible course of the risk causes psychological problems in hemodialysis patients.

Depression is the most common psychological complication that has a serious impact on the quality of life of hemodialysis patients and their social, economic, and psychological well-being (Anees et al., 2011). Depression manifests primarily with sadness, anxiety, depressed mood, poor self- esteem, pessimism about the future, decreased libido, sleep disturbance, and limited appetite (Gerogianni and Babatsikou, 2014).

According to WHO, depression is a mental disorder characterized by sadness, loss of interest or pleasure, feelings of guilt or low self-esteem, sleep or appetite disorders, feelings of fatigue, and poor concentration. Depression can be long-lasting, repetitive, and can disrupt individuals in their normal daily activities. Severe depression can cause individuals to commit suicide (WHO, 2017).

There was a relationship between depression and high mortality in hemodialysis patients in the long run. In general population, the prevalence of major depression was $1.1 \%-15 \%$ in males and $1.8 \%$ $-23 \%$ in females. However, in hemodialysis patients, the prevalence was much higher at around 20\% $-30 \%$ and can even reach a prevalence of $47 \%$ (Chen et al., 2010).

A study shows that patients with EndStage Renal Disease (ESRD) had a 4 times higher risk of depression than general population (Hedayati et al., 2008a). In the United States, the incidence of suicide in hemodialysis patients was 500 times more than in general population. However, refusal to do hemodialysis can be considered as a subtle attempt to suicide (Chen et al., 2010).

One study has reported that depression contributed tothe highest annual mortality of hemodialysis patients in Pakistan, compared with patients in Western countries (Hedayati et al., 2008b). During the period of the hemodialysis therapy, one in 500 patients attempted suicide or violated dietary rules (Gerogianni and Babatsikou, 2014).

In the first 1-3 weeks, patients with acute renal impairment will be relatively easier to accept the process of hemodialysis. Opposing this feeling, patients with chronic kidney failure experience strong fear and anxiety for disability or death, as well as fears of social and financial problems as they have 
to accept the fact that they have to undergo hemodialysis for life. During this period, patients experience sleep disorders, depressive symptoms, and strong concerns about the loss of self-autonomy, work, family roles, and sexual function (Gerogianni and Babatsikou, 2014).

Although the incidence of depression in hemodialysis patients is quite high, the diagnosis is often overlooked. Existing health services only focus on the physical aspects of the disease, and thus they need also to emphasize on considering psychological aspects, including depression due to chronic medical diseases linked to suicidal tendencies and affects survival rates (Saeed et al., 2012.

Jemursari Islamic Hospital is one of the hospitals providin a hemodialysis center facility in Surabaya. Based on the Main Branch Office Social Security Administering Bodies Surabaya, Jemursari Islamic Hospital has become the second hospital with the highest number of hemodialysis procedure services after Dr. Soetomo since 2016. In 2016, the hospital served 13,002 hemodialysis actions. Further, it provided 14,410 hemodialysis actions in 2017 and 15,750 actions in 2018. The number of hemodialysis patients continues to increase, and so does the psychological burden .

Although the hemodialysis procedure is used to maintain patient survival, patient's life expectancy remains a problem. Based on the research conducted by Yulianto and Basuki (2018), the survival of patients with CKD who underwent hemodialysis was on average 67.84 months. The survival of CKD patients who underwent hemodialysis was lower in female patients, in the age group of 46-65 years, in those with the frequency of hemodialysis of more than 3 times and a history of disease and complications.

Life which depends on a dialysis machine and is in uncertainty can be a powerful stressor for psychological problems such as symptoms of depression. Therefore, this study highlighted to identify to what extent hemodialysis patients at Jemursari Hospital in Surabaya experienced depressive symptoms .

\section{METHODS}

This study was a descriptive study with a cross-sectional approach. It was conducted in May 2019 in the Hemodialysis Room of the Jemursari Islamic Hospital in Surabaya.

The research population was all regular (scheduled) hemodialysis patients at the hospital in May 2019. The study sample was 72 regular (scheduled) hemodialysis patients who met the inclusion criteria.The patients should have regular hemodialysis treatment, be able to communicate, have consciousness, and agree to participate by signing informed consent forms. While this study applies exclusion criteria to hemodialysis patients with stroke, patients or their families who refused to participate, those in unfit condition andimpossibly unable for interview until the data collection was complete.

The respondents were selected using probability sampling, in which the researchers took the same opportunity for members of the population to be selected as samples. Specifically, simple random sampling was done through a random draw on the roster of regular hemodialysis patients.

This study only used one variable, depressive symptoms. Data collection was done through interview when the patients were queuing for hemodialysis therapy or while patients were in the hemodialysis process

by taking into account the patient's state of consciousness and fitness.

Measurement of depressive symptoms was done using the Beck Depression Inventory instrument developed by Aaron T. Beck in 1961. Depression symptoms were observed from respondents' self-assessement (self-report inventory). 
To analyze the data, this study performed a univariate analysis by looking at the frequency distribution of depression symptoms. The results of the study were presented in the form of frequency and narrative tables and compared with other similar studies. This study has obtained ethical clearance from the Ethics Commission of Commission on Research Ethics Jemursari Islamic Hospital Surabaya (No: 005 / KEPK-RSI JS / V / 2019).

\section{RESULTS}

Overview of Depression Symptoms in Hemodialysis Patients

Table 1. Description of Depression Symptoms in Hemodialysis Patients.

\begin{tabular}{ccc}
\hline $\begin{array}{c}\text { Depression } \\
\text { Symptom } \\
\text { Levels }\end{array}$ & Frequency (n) & $\boldsymbol{\%}$ \\
\hline Normal & 23 & 31.9 \\
Mild & 30 & 41.7 \\
Moderate & 16 & 22.2 \\
Heavy & 3 & 4.2 \\
\hline Total & $\mathbf{7 2}$ & $\mathbf{1 0 0}$ \\
\hline
\end{tabular}

Based on the results, of 72 respondents, 49 respondents $(68.1 \%)$ experienced depression symptoms. The majority of respondents had experienced mild depressive symptoms (41.7\%). A total of 16 respondents $(22.2 \%)$ experienced moderate depression symptoms, and 3 respondents $(4.2 \%)$ experienced severe depression symptoms.

This study also indicates that of 72 respondents, 20 respondents $(27.8 \%)$ claimed to feel sad, 22 respondents $(30.6 \%)$ felt pessimistic, 23 patients $(31.9 \%)$ thought their disease was a failure, and 34 patients $(47.2 \%)$ lost their pleasure. Moreover, nearly half of the respondents $(48.6 \%)$ felt guilty, 40 patients $(55.6 \%)$ considered the disease as a punishment, and 19 patients $(25.4 \%)$ felt selfloathing. As many as 17 patients (23.6\%) criticized themselves more, but none of the respondents thought about suicide. Some patients $(36.1 \%)$ cried more, 26 patients (36.1\%) experienced agitation, 18 patients (25\%) lost interest, and 23 patients (31.9\%) had difficulty in making decisions. Further, 22 patients $(30.6 \%)$ felt worthless, 40 patients $(55.6 \%)$ lost energy, 50 patients $(69.4 \%)$ experienced sleep disorders, and 47 patients $(65.3 \%)$ got angry easily. Additionally, there were 25 patients $(34.7 \%)$ experiencing changes in diet, 27 patients $(37.5 \%)$ had difficulty in concentrating, 48 patients $(66.7 \%)$ felt fatigued, and 56 patients $(77.8 \%)$ lost interest towards sex.

\section{Overview of Depression Symptoms in Hemodialysis Patients by Gender}

Regarding gender distribution, out of 49 patients who had depression symptoms, 31 patients $(63.3 \%)$ were male, and 18 patients $(36.7 \%)$ were female. There were 17 male respondents who experienced mild depression symptoms (24.5\%), and 2 male respondents had severe depression symptoms $(4.1 \%)$. While female respondents mosly experienced mild depression symptoms $(56.5 \%)$.

Table 2. Description of Depression Symptoms in Hemodialysis Patients by Gender.

\begin{tabular}{cccccc}
\hline \multirow{2}{*}{ Gender } & \multicolumn{5}{c}{ Depression } \\
& $\begin{array}{c}\text { Sorm } \\
\text { al }\end{array}$ & Mild & $\begin{array}{c}\text { Moder Heav } \\
\text { ate }\end{array}$ & y \\
\cline { 2 - 5 } & 18 & 17 & 12 & 2 & 49 \\
\multirow{2}{*}{ Male } & $36.7 \%$ & $34.7 \%$ & $24.5 \%$ & $4.1 \%$ & $100 \%$ \\
\hline \multirow{2}{*}{ Female } & 5 & 13 & 4 & 1 & 23 \\
& $21.7 \%$ & $56.5 \%$ & $17.4 \%$ & $4.4 \%$ & $100 \%$ \\
\hline \multirow{2}{*}{ Total } & 23 & 30 & 16 & 3 & 72 \\
& $31.9 \%$ & $41.7 \%$ & $22.2 \%$ & $4.2 \%$ & $100 \%$ \\
\hline
\end{tabular}


Overview of Depression Symptoms in Hemodialysis Patients by Age

Based on age, of 49 respondents who experienced depression symptoms, 24 of them (49\%) were in the age group of 46-65 years. In the same age group, 12 patients $(36.4 \%)$ had mild depression symptoms. Whereas 10 patients $(30.3 \%)$ experienced moderate depression symptoms, and 2 patients $(6 \%)$ experienced severe depression symptoms.

Table 3. Description of Depression Symptoms in Hemodialysis Patients by Age.

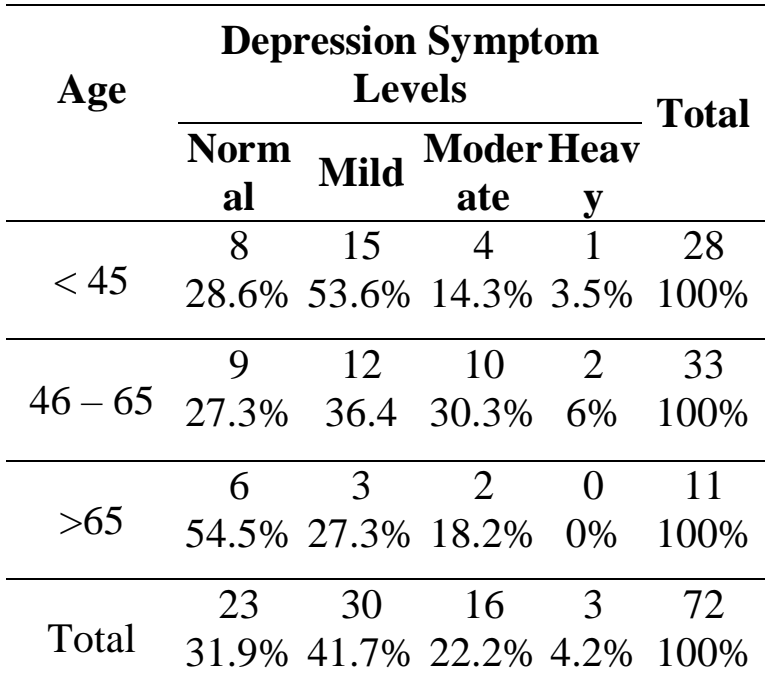

Overview of Depression Symptoms in Hemodialysis Patients by Education

The results of cross-tabulation presents the respondents' education levels. Table 4 shows that of 49 respondents who experienced depression symptoms, 17 patients $(34.7 \%)$ had completed high schoolTwelve respondents (46.2\%) who completed high school experienced mild depression symptoms, and 5 respondents (19.2\%) experienced moderate depression symptoms.
Table 4. Description of Depression Symptoms in Hemodialysis Patients by Education

\begin{tabular}{cccccc}
\hline \multirow{2}{*}{ Education } & \multicolumn{5}{c}{$\begin{array}{c}\text { Depression Symptom } \\
\text { Levels }\end{array}$} \\
\cline { 2 - 6 } & $\begin{array}{c}\text { Norm } \\
\text { al }\end{array}$ & Mild $\begin{array}{c}\text { Moder } \\
\text { ate }\end{array}$ & Total \\
\hline $\begin{array}{c}\text { Not } \\
\text { completed } \\
\text { elementary } \\
\text { school }\end{array}$ & $0 \%$ & 1 & 1 & 1 & 3 \\
\hline Elementary & 1 & $33.3 \%$ & $33.3 \%$ & 33.4 & $100 \%$ \\
school & $14.3 \%$ & $42.8 \%$ & $28.6 \%$ & 14.3 & $100 \%$ \\
\hline Junior high & 4 & 6 & 5 & 1 & 16 \\
school & $25 \%$ & $37.5 \%$ & 31.25 & 6.25 & $100 \%$ \\
& & & $\%$ & $\%$ & \\
\hline High & 9 & 12 & 5 & 0 & 26 \\
school & $34.6 \%$ & $46.2 \%$ & $19.2 \%$ & $0 \%$ & $100 \%$ \\
\hline Bachelors & 9 & 8 & 3 & 0 & 20 \\
& $45 \%$ & $40 \%$ & $15 \%$ & $0 \%$ & $100 \%$ \\
\hline Total & 23 & 30 & 16 & 3 & 72 \\
\hline & $31.9 \%$ & $41.7 \%$ & $22.2 \%$ & $4.2 \%$ & $100 \%$ \\
\hline
\end{tabular}

Overview of Depression Symptoms in Hemodialysis Patients by Marital Status

Table 5. Description of Depression Symptoms in Hemodialysis Patients by Marital Status.

\begin{tabular}{lccccc}
\hline \multirow{2}{*}{$\begin{array}{c}\text { Marital } \\
\text { status }\end{array}$} & \multicolumn{4}{c}{$\begin{array}{c}\text { Depression Symptoms } \\
\text { Levels }\end{array}$} & Torm \\
& al & Mild & $\begin{array}{c}\text { Moder Heav } \\
\text { ate }\end{array}$ & y \\
\cline { 2 - 6 } Not & 4 & 6 & 4 & 1 & 15 \\
Married / & $26.7 \%$ & $40 \%$ & $26.7 \%$ & $6.6 \%$ & $100 \%$ \\
Divorced & & & & & \\
\hline Married & 19 & 24 & 12 & 2 & 57 \\
& $33.3 \%$ & $42.2 \%$ & $21 \%$ & $3.5 \%$ & $100 \%$ \\
\hline \multirow{2}{*}{ Total } & 23 & 30 & 16 & 3 & 72 \\
& $31.9 \%$ & $41.7 \%$ & $22.2 \%$ & $4.2 \%$ & $100 \%$ \\
\hline
\end{tabular}

Thirty-eight patients out of 49 respondents $(77.5 \%)$ were married. Nearly half of the married patients experienced mild depression symptoms (42.2\%), 12 of them 
(21\%) experienced moderate depression symptoms, and 2 patients $(3.5 \%)$ experienced severe depression symptoms.

Overview of Depression Symptoms in Hemodialysis Patients by Employement Status

The results of cross-tabulation between employement status and depression symptoms present the majority of respondents who had depression symptoms did not work. Based on the employment status, 38 patients with depression symptoms (77.5\%) did not work. Of these patients, 25 patients (51\%) had mild depression symptoms, 12 patients $(24.5 \%)$ had moderate depressive symptoms, and only one patient (2\%) had severe depression symptoms.

Table 6. Description of Depression Symptoms in Hemodialysis Patients by Employement Status.

\begin{tabular}{cccccc}
\hline & \multicolumn{5}{c}{$\begin{array}{c}\text { Depression Symptom } \\
\text { Levels }\end{array}$} \\
\cline { 2 - 5 } Job-status & $\begin{array}{c}\text { Norm } \\
\text { al }\end{array}$ & Mild & $\begin{array}{c}\text { Moder Heav } \\
\text { ate }\end{array}$ & Total \\
\hline \multirow{2}{*}{ No Labor } & 11 & 25 & 12 & 1 & 49 \\
& $22.5 \%$ & $51 \%$ & $24.5 \%$ & $2 \%$ & $100 \%$ \\
\hline \multirow{2}{*}{ Labor } & 12 & 5 & 4 & 2 & 23 \\
& $52.2 \%$ & $21.7 \%$ & $17.4 \%$ & $8.7 \%$ & $100 \%$ \\
\hline \multirow{2}{*}{ Total } & 23 & 30 & 16 & 3 & 72 \\
& $31.9 \%$ & $41.7 \%$ & $22.2 \%$ & $4.2 \%$ & $100 \%$ \\
\hline
\end{tabular}

Overview of Depression Symptoms in Hemodialysis Patients by Hemodialysis Treatment Duration

This study finds the majority of people with depression symptoms had undergone hemodialysis for more than 12 months $(67.3 \%)$. In the group who underwent hemodialysis treatment, 21 patients $(42.8 \%)$ experienced mild depression symptoms, 11 patients $(22.5 \%)$ experienced moderate depression symptoms, and 1 person $(2.1 \%)$ had severe depression symptoms.

Table 7. Description of Depression Symptoms in Hemodialysis Patients by Hemodialysis Treatment Duration.

\begin{tabular}{|c|c|c|c|c|}
\hline \multirow{2}{*}{$\begin{array}{l}\text { Hemodialysi } \\
\text { s Treatment } \\
\text { Duration }\end{array}$} & \multicolumn{3}{|c|}{$\begin{array}{c}\text { Depression Symptom } \\
\text { Levels }\end{array}$} & \multirow{2}{*}{ Total } \\
\hline & $\begin{array}{c}\text { Norm Light } \\
\text { al }\end{array}$ & $\begin{array}{l}\text { Moder } \\
\text { ate }\end{array}$ & $\begin{array}{c}\text { Weig } \\
\text { ht }\end{array}$ & \\
\hline \multirow{2}{*}{$<12$ months } & 7 & 5 & 2 & 23 \\
\hline & $30.5 \% 39.1 \%$ & $21.7 \%$ & $8.7 \%$ & $100 \%$ \\
\hline$\geq 12$ months & 16 & 11 & 1 & 49 \\
\hline \multirow[b]{2}{*}{ Total } & $32.6 \% 42.8 \%$ & $22.5 \%$ & $2.1 \%$ & $100 \%$ \\
\hline & $31.9 \% 41.7 \%$ & $22.2 \%$ & $4.2 \%$ & $100 \%$ \\
\hline
\end{tabular}

\section{DISCUSSION}

\section{Overview of Depression Symptoms in Hemodialysis Patients}

This study reports the prevalence of depression symptoms in hemodialysis patients was by $68.1 \%$. It is relevant with the AlDukhayel's study (2015) which shows high prevalence of depression symptoms in hemodialysis patients. Research conducted by Ambarsari (2017) at Wates Hospital Yogyakarta also reports that $89.2 \%$ depression symptoms occurred to hemodialysis patients.

Hemodialysis patients at Jemursari Hospital in Surabaya mostly experienced mild depression symptoms (41.7\%). TSimilarly, Amalia (2015) reports that the majority of respondents $(37.5 \%)$ had mild depression symptoms. Further, Alukukayel's research (2015) indicates $39.1 \%$ of hemodialysis patients experienced mild depression symptoms using the Beck Depression Inventory (BDI) instrument.

The analysis of 21 items in depression symptom variable shows $77.8 \%$ of patients lost interest in sex, $66.7 \%$ experienced fatigue, $69.4 \%$ had sleep disorders, and 65.3 
$\%$ got angry easily. In with these findings, Ritland (1996) also find that $43.5 \%$ of patients lost interest in sex, $81.5 \%$ experienced fatigue, $62.5 \%$ experienced sleep disorder, and $43 \%$ claimed to be more offended.

Someone undergoing a hemodialysis therapy can lose self-freedom and social relations (Thong et al., 2007). Many factors trigger depression in hemodialysis patients such as family support, age, education level, and marital status (Theofilou, 2011). Besides, stressors originate from the lives of the hemodialysis patients themselves. These stressors include dietary restrictions and time problems, body function limitations, job loss, changes in self-perception, changes in reproductive function, perceived effects of the disease, drug use, costs, and worries related to care, uncertainty and anxiety, and fear of death (Kimmel, 2001).

Preventing and overcoming depression symptoms in hemodialysis patients is vital because it is also associated with other adverse effects, including poor nutritional status and patient compliance with treatment (Watnick et al., 2003).

\section{Overview of Depression Symptoms in Hemodialysis Patients by Gender}

The results of this study show most male patients experienced mild depression symptoms (34.7\%). This study indicates men had more depression symptoms than women. It is supported by the result of research conducted by Alukukayel (2015) 56 male patients mostly experienced depression symptoms (84.8\%). Further, Endris, Fikreyesusand Amare (2019) also discover that among 257 hemodialysis patients with symptoms, 158 patients $(61.5 \%)$ were male.

According to Saeed et al. (2012), stress during treatment and the burden of treatment cost affect the whole family and patients who are the heads of the household.
This contradicts the finding of Ruli's research (2008) which states that men were more susceptible to chronic kidney failure than women. However, in terms of depression, women developed depression more easily than men. Women generally can acknowledge depression more compared to men, and thus doctors can handle depression better in women.

\section{Overview of Depression Symptoms in Hemodialysis Patients by Age}

This study informs us that the age group of 46-65 years (elderly) (49\%) were more susceptible to depression symptoms. In this age group, 12 respondents $(36.4 \%)$ who experienced mild depression symptoms. IIn the same way, Rustina (2012) discovers that the majority of respondents with depression symptoms were in the age group of 51-56 years or in the category of early elderly. Further, Ambarsari (2017) elaborates that the majority of respondents with depression symptoms were aged between 46-55 years, and $38.4 \%$ of them had mild depression symptom rate of $24.6 \%$.

According to Nevid et al. (2003), the incidence of depression mostly occurs to elderly. Health condition in old age is less fit compared to young age. Several other physical ailments in elderly may cause complications of diseases that trigger depression.

\section{Overview of Depression Symptoms in Hemodialysis Patients by Education}

Education is one of the factors that can influence somone's knowledge, attitudes, and actions. Good knowledge is the basis to determine attitude and actions, for example adjusting to changes in health status. This study informs us that most respondents with depression symptoms completed high school (34.7\%). This result is in line with Rustina's study (2012) which states that the majority of respondents (17.9\%) who experienced 
depression symptoms completed high school. Also, research from Amalia (2015) points out $57.14 \%$ of respondents with depression symptoms had high school education, and $42.87 \%$ of these respondents had mild depression symptoms.

Contrastly, Mukadder et al. (2004) discover that the lower the level of patient education, the higher the Beck Depression Inventory score. Besides, Binbay et al. (2015) also state that the prevalence of depression was high in hemodialysis patients with low levels of education and socioeconomic status.

\section{Overview of Depression Symptoms in Hemodialysis Patients by Marital Status}

Most of the respondents who suffered from depression symptoms $(77.5 \%)$ were married. Most of them experienced mild depression symptoms (42.2\%). This is in line with Rustina's research (2012) which shows $34.33 \%$ of the research respondents had been married, and $26.87 \%$ of them experienced mild depressive symptoms. Endris, Fikreyesus and Amare (2019) reveal that out of 257 hemodialysis patients with depression symptoms, 137 people $(53.3 \%)$ were married. Saeed et al. (2012) report that the incidence of depression was higher among hemodialysis and peritoneal dialysis patients who were married.

Married people who do not work could be at risk of experiencing moderate to severe depression. Marriage has given people great responsibility to maintain family's economic and social support (Saeed et al. 2012). Moreover, hemodialysis patients have more difficulty in adapting to their partners than healthy people, and such difficulty leads them to experience depression and anxiety (Tavallaii et al., 2009).

Chronic kidney disease may cause disorganized roles in a marital relationship. Sexual dysfunction also causes problems in a marital relationship (Palmer, 2003). Patients who were previously sexually active and had no fertility problems begin to experience weaker conditions such as loss of sex drive.

A previous study at Zainoel Abidin Regional Hospital in Banda Aceh, the respondents experienced some psyschological problems, such as fatigue, energy loss, and loss of interest in sex (Yokha, 2012). Fatigue was the most common complaint that hemodialysis patients had at the hospital. The high risk of fatigue could limit patients' activity, including sexual activity.

\section{Overview of Depression Symptoms in Hemodialysis Patients by Employement Status}

This study reports the majority of the respondents were unemployed. This is consistent with research by Saeed et al. (2012) who find $81 \%$ of hemodialysis patients did not work and felt depressed. According to Armaly et al. (2012), the tendency for depression will increase in people with lower living standards and socioeconomic status.

Changes in physical abilities due to chronic kidney disease limit patients to keep working. As a result, those who serve as the heads of their family would feel depressed as they cannot fulfill their roles. A study in Iraq further points out that the main factors for depression in hemodialysis patients were the unemployement and marriage (Hamody et al., 2013).

\section{Overview of Depression Symptoms in Hemodialysis Patients by Hemodialysis Treatment Duration}

This study discloses most of the respondents $(67.3 \%)$ had undergone hemodialysis therapy for more than 12 months. It is consistent with Ambarsari's research (2017) which shows that the majority of respondents with depression symptoms (64.6\%) had undergone hemodialysis therapy for 1-5 years. Duration 
of hemodialysis therapy which takes 2 to 3 times a week greatly affects the patient's condition both physically and psychologically. Fear and worry about various future consequences are feelings that the patients commonly felt as they always depend on hemodialysis therapy forever (Butar and Siregar, 2012).

\section{CONCLUSION}

Most patients undergoing hemodialysis in May 2019 at Jemursari Hospital Surabaya experienced depression symptoms. The majority experienced mild depression symptoms and were males. The patients mostly were in the age group of 4665 years, completed high school, and were married. Furthermore, since chronic kidney disease has caused limitations in performing activities, most patients were unemployed. Most of them had undergone hemodialysis therapy for more than 12 months.

\section{REFERENCE}

AlDukhayel, A. 2015. Prevalence of Depressive Symptoms among Hemodialysis and Peritoneal Dialysis Patients. International journal of health sciences. 9(1). pp. 9-16.

Amalia, F., Nadjmir and Azmi, S. 2015. Gambaran Tingkat Depresi pada Pasien Penyakit Ginjal Kronik yang Menjalani Hemodialisis di RSUP DR. M. Djamil Padang. Jurnal.Fk.Unand.Ac.Id. 4(1). pp. 115-121.

Anees, M., Hameed, F., Mumtaz, A., Ibrahum, M., Saeed, Khan. 2011. Dialysis-related factors affecting quality of life in patients on hemodialysis. Iranian Journal of Kidney Diseases. 5(1). pp. 9-14.

Armaly, Z. et al. 2012. Major depressive disorders in chronic hemodialysis patients in Nazareth: Identification and assessment. Neuropsychiatric Disease and Treatment. 8. pp. 329338. doi: 10.2147/NDT.S31903.

Binbay, T. et al. 2015. The epidemiology of major depressive disorder and subthreshold depression in Izmir, Turkey: Prevalence, socioeconomic differences, impairment and helpseeking. Journal of Affective Disorders. pp. 78-86. doi: 10.1016/j.jad.2015.04.017.

Social Health Insurance Administration Agency (BPJS). 2016. Infobpjs Media Eksternal BPJS Kesehatan. [Online]

Butar, A. and Siregar, C. T. 2012. Karakteristik Pasien Dan Kualitas Hidup Pasien Gagal Ginjal Kronik Yang Menjalani Terapi Hemodialisa. Jurnal Keperawatan Klinis. Fakultas Keperawatan USU. 4(1).

Chan, R. et al. 2009. The effects of kidneydisease-related loss on long-term dialysis patients' depression and quality of life: positive affect as a mediator. Clinical journal of the American Society of Nephrology: CJASN. 4(1). pp. 160-167. doi: 10.2215/CJN.01520308.

Chen, C.-K. et al. 2010. Depression and suicide risk in hemodialysis patients with chronic renal failure. Psychosomatics. England. 51(6). pp. 528-528.e6. doi: 10.1176/appi.psy.51.6.528.

Edo, YP. 2012. Gambaran gejala depresi pada pasien yang sedang menjalani terapi hemodialisis di instalasi dialisis rsud dr zainoel abidin banda aceh. Skripsi. Universitas Syiah Kuala.

Endris, B., Fikreyesus, M. and Amare, T. 2019. Prevalence of depression and associated factors among haemodialysis patients at government and private hospitals in Addis Ababa. African Journal of Nephrology. 21(1). pp. 56-60. doi: 10.21804/21-1-2943.

Gerogianni, S. K. and Babatsikou, F. P. 2014. 
Psychological aspects in treatment of chronic renal failure. Social Science \& Medicine (1967). 8(2). pp. 205$214 . \quad$ doi: $10.1016 / 0037-$ 7856(68)90007-3.

Hamody, A. R. T. et al. 2013. Depression in Iraqi hemodialysis patients. Arab journal of nephrology and transplantation. 6(3). pp. 169-72.

Hedayati, S. S. et al. 2008a. Death or hospitalization of patients on chronic hemodialysis is associated with a physician-based diagnosis of depression. Kidney International. Elsevier Masson SAS. 74(7). pp. 930936. doi: 10.1038/ki.2008.311.

Hedayati, S. S. et al. 2008b. Death or hospitalization of patients on chronic hemodialysis is associated with a physician-based diagnosis of depression. Kidney International. Elsevier Masson SAS. 74(7). pp. 930936. doi: 10.1038/ki.2008.311.

Indonesian, P., Registry, R. and Course, H. 2014. 10 th Report Of Indonesian Renal Registry 2017.

KDIGO. 2012. Clinical Practice Guideline for the Evaluation and Management of Chronic Kidney Disease. Official Journal of The International Society of Nephrology. 3(1). doi: 10.1038/kisup.2012.76.

Kimmel, P. L. 2001. Psychosocial factors in dialysis patients. Kidney International. Elsevier Masson SAS. 59(4). pp. 1599-1613. doi: $10.1046 / \mathrm{j} .1523-$ 1755.2001.0590041599.x.

Mollaoglu, M. 2004. Depression and healthrelated quality of life in hemodialysis patients. Dial. Transplant. 544-549.

National Kidney Foundation. 2013. HEMODIALYSIS: What You Need to Know. National Kidney Foundation. pp. 1-27. doi: 10.1016/j.matlet.2011.04.090.

Nevid, Jeffrey S. 2003. Psikologi Abnormal
Edisi Kelima Jilid 1. Erlangga:Jakarta.

Palmer, B. F. 2003. Sexual Dysfunction in Men and Women With Chronic Kidney Disease and End-Stage Kidney Disease', Advances in Renal Replacement Therapy. Elsevier. 10(1). pp. 48-60.

Regulation of the Ministry of Health of the Republic of Indonesia Number 812/Menkes/PER/VII/2010

concerning the Implementation of Dialysis Services in Health Care Facilities

Ministry of Basic Health Research. 2013. Riset Kesehatan Dasar Kementerian RI. Riset Kesehatan Dasar Kementerian RI. doi: 1 Desember 2013.

Ritland, K. 1996. Depression in Hemodialysis Patients. Bosn J Basic Med Sci. 8(1). pp. 1-8.

Rustinaa. 2012. Gambaran Tingkat Depresi Pada Pasien Gagal Ginjal Kronik Yang Menjalani Hemodialisis Di Rsud Dr. Soedarso Pontianak Tahun 2012. Universitas Tanjungpura Pontianak.

Saeed et. al. 2012. Depression in patients on hemodialysis and their caregivers. Saudi Journal of Kidney Diseases and Transplantation. 23(5). p. 946. doi: 10.4103/1319-2442.100869.

Sari, S. A. 2017. Gambaran Tingkat Depresi Pada Pasien Gagal Ginjal Kronis Yang Menjalani Terapi Hemodialisa Di Rumah Sakit Umum Daerah Wates Yogyakarta. Stikes Jendral Achmad Yani Yogyakarta.

Tavallaii, S. A. et al. 2009. Marital adjustment in patients on long-term hemodialysis: A case-control study. Iranian Journal of Kidney Diseases, 3(3). pp. 156-161.

Thong, M. S. Y. et al. 2007. Social support predicts survival in dialysis patients. Nephrology Dialysis Transplantation. 
22(3). pp. $\quad 845-850 . \quad$ doi: $10.1093 / \mathrm{ndt} / \mathrm{gfl} 700$.

Topuzołlu, A. et al. 2015. The epidemiology of major depressive disorder and subthreshold depression in Izmir, Turkey: Prevalence, socioeconomic differences, impairment and helpseeking. Journal of Affective Disorders. 181. pp. 78-86. doi: 10.1016/j.jad.2015.04.017.

Watnick, S. et al. 2003. The prevalence and treatment of depression among patients starting dialysis. American Journal of Kidney Diseases. United States. 41(1). pp. 105-110. doi: 10.1053/ajkd.2003.50029.

World Health Organization. 2017. World Health Organization Report Depression and Other Common Mental Disorders: Global Health Estimates. World Health Organization. pp. 1-24. doi: CC BYNC-SA 3.0 IGO.

Yulianto, D. and Basuki, H. 2018. Analisis Ketahanan Hidup Pasien Penyakit Ginjal Kronis Dengan Hemodialisis Di RSUD Dr. Soetomo Surabaya. Jurnal Manajemen Kesehatan Yayasan RS.Dr. Soetomo. 3(1). p. 96. doi: 10.29241/jmk.v3i1.92. 